\title{
İnek sütü protein alerjisi
}

Cow's-milk protein allergy

\author{
Tuğba Koca, Mustafa Akçam
}

\section{ÖZET}

İnek Sütü Protein Alerjisi (ISPA) erken çocuklukta en sık görülen besin alerjisidir. Süt çocuklarının \%2-3'ünde görülür. IgE aracılı veya IgE aracılı olmayan, birden fazla sistemi ilgilendiren klinik yakınmalar ile karşımıza çıkar. Genellikle erken çocukluk döneminde görülür ve geçicidir. Tanıda ilk ve en önemli basamak iyi alınmış bir öyküdür. Laboratuar testleri tek başına tanı koydurmaz, daima klinik ile birlikte değerlendirilmelidir. ISPA birden fazla immünolojik mekanizma ile oluşabildiğinden birden fazla testin bir arada kullanılması tanı şansını artıır. Ancak testlerin negatif olması tanıyı dışlamaz. Tanıda altın standart eliminasyon diyeti ve besin yükleme testidir. İnek sütü ve ürünlerinin kullanımından kaçınma, hala tüm çocuklarda iSPA tedavisinde ilk seçenek olarak kabul edilmektedir.

Anahtar kelimeler: Eliminasyon diyeti, inek sütü protein alerjisi, tedavi, yükleme testi

\section{TANIM}

Besin ve besin katkı maddelerine karşı vücutta oluşan her türlü anormal klinik cevaba "besin aşırı duyarlılığı" denir. Besin aşırı duyarlılığı fizyolojik mekanizmalarla oluşuyorsa 'besin intoleransı', immünolojik mekanizmalarla oluşuyorsa 'besin alerjisi' olarak adlandırılır [1]. İnek sütünde bulunan proteinlere karşı immünolojik mekanizmalarla oluşan reaksiyonlara inek sütü protein alerjisi (ISSPA) denir. Genel olarak sık görülen hastalıklar açısından besin alerjisi sik sayılamaz. Ancak tanısal sorunlar ve algılamada netlik olmaması bir sosyal yük oluşmasına yol açar.

\begin{abstract}
Cow's Milk Protein Allergy (CMPA) is the most common food allergy in early childhood. It affects between $2 \%$ and $3 \%$ of infants. Symptoms and signs related to CMPA which IgE-mediated or non IgE-mediated may involve many different organ systems. The first and most important step in diagnosis is a thorough medical history. Results of laboratory tests alone are not sufficient to make diagnosis, always need to be considered together with the clinical features. CMPA can occur with multiple immunological mechanisms, therefore the diagnosis chance increases with use of numerous tests together. However, the negative test does not exclude the diagnosis. The gold standards in diagnosis are food elimination and challenge tests. Cow's milk and avoiding the use of its products, it is still considered as the first choice in the treatment of all children with CMPA.
\end{abstract}

Key words: Elimination diet, cow's-milk protein allergy, treatment, oral challenge

\section{İNEK SÜTÜ ALERJEN PROTEINLERI}

İSPA inek sütünün proteinlerine karşı gelişir. İnek sütünde insanlarda antikor yapımına neden olabilecek en az 20 protein bileşeni bulunur [2]. İnek sütü proteininin \%80'ini kazein, \%20'sini whey oluştur. Kazein; $\alpha$ s1, $\alpha$ s2, $\beta$, ve $\kappa$ kazein proteinlerinden oluşmuştur. Whey proteini ise $\beta$-laktoglobulin, $\alpha$-laktalbumin, sığır serum albumini ve küçük miktarlarda çeşitli proteinler (laktoferin, transferin, lipaz, esteraz) içerir. Çocukta genellikle birden fazla proteine karşı duyarlılık gelişir; en sık alerjiye yol açanlar kazein, $\beta$-laktoglobulin, $\alpha$-laktalbumin kısımlarıdır [3]. $\beta$-laktoglobulin insan sütünde bu-

Süleyman Demirel Üniversitesi Tip Fakültesi, Çocuk Gastroenteroloji, Hepatoloji ve Beslenme BD, Isparta, Türkiye

Yazışma Adresi /Correspondence: Tuğba Koca,

Süleyman Demirel Üniversitesi Tıp Fakültesi, Çocuk Gastroenteroloji\&Hepatoloji BD, Isparta, Türkiye

Geliş Tarihi / Received: 15.01.2015, Kabul Tarihi / Accepted: 29.05.2015

Email: tgkoca@gmail.com

Copyright (C) Dicle Tıp Dergisi 2015, Her hakkı saklıdır / All rights reserved 
lunmaz. Süt alerjenleri kaynatma, pastörizasyon ve evoporasyon işlemlerinden sonra da biyolojik aktivitelerini korurlar [3,4].

\section{EPIDEMIYOLOJI}

İnek sütü günlük hayatımızda beslenmemizde önemli bir yer tutan hayvansal gıdaların başında gelmektedir. Süt çocuklarının beslenmesine giren ilk yapancı protein inek sütüdür. Dolayısıyla genel olarak immünolojik tolerans mekanizmaları immatür olan bebek ve küçük çocukları arasında en sık rastlanan besin alerjisi olma özelliği taşır [5]. Sadece yakınmalar göz önünde bulundurulduğunda anne babalar çocuklarında İSPA'yı gerçekte var olandan daha s1k olarak algılarlar. İSPA sıklığı süt çocukluğu döneminde yaklaşık \%2-3'tür [6]. Yaşamın ilk y1lında pik yapaktadır [7]. Altı yaş ve üzerinde sıklı̆̆ 1 $\% 1$ 'in altına düşer. Sadece anne sütü ile beslenen bebeklerde de \%0,5 oranında bildirilmiştir [5].

\section{PATOGENEZ}

Gastrointestinal sistem, yabancı antijenleri bloke ederek onların dolaşıma girmesini engelleyecek, immunolojik ve immunolojik olmayan komponentlere sahiptir. Antijen sunan hücreler, retiküloendotelyal sistemde bulunurlar ve oral tolerans gelişiminde rol oynarlar. Retiküloendotelyal sistemi aktive eden faktörler, bu hücrelerin aktivasyonunu artırarak, CD8(+) hücre oluşumunu engelleyerek oral tolerans gelişimini azaltırlar. Küçük süt çocuklarında besinlere karş1 ileri derecede hassasiyetin nedeni, alınan protein miktarının fazlalığına, bağırsaktaki salgısal IgA düzeyinin düşük olmasına ve bağırsak ilişki lenfoid dokunun olgunlaşmasının tamamlanmamasına bağlıdır [8].

Oral tolerans gelişiminde ortaya çıkan bir yetersizlik, besine özgü IgE antikorlarının aşırı üretimi ile sonuçlanır. İSPA, IgE ve hücre aracılığ ile olabilmektedir. Büyük olasılıkla bu iki mekanizmanın her ikisi birden alerjide rol oynamaktadır [9].

IgE arac1lı reaksiyonlar: Besine özgü IgE antikorlarının aşırı üretimi söz konusudur. Besin alerjenleri mukozal bariyerlere yayıldıklarında ve mast hücre, bazofil hücre yüzeyine bağlanmış olan $\operatorname{IgE}$ moleküleri arasında çapraz bağlanma meydana gelir. Bunun sonucunda mast hücreleri ve bazofillerden çeşitli mediyatörler salgılanması sonucu ani aşırı duyarlılık yakınmalarıyla sonuçlanan damar genişlemesi, düz kas kasılması ve mukus sekresyon artışına neden olur. Yakınmaların ortaya çıkışı hız11dır. Alerjene maruziyetten sonra dakikalar ile saatler içinde yakınmalar ortaya çıktığı için IgE aracılı alerji sıklıkla ani başlayan hipersensitivite olarak da bilinir [10].

IgE arac1lı olmayan reaksiyonlar: İmmünolojik mekanizmalar halen kesin olarak açıklanmış değildir. TH1 aracılı reaksiyonlar, kompleman aktivasyonunun öncülük ettiği immun komplekslerin birikimi veya T hücre/mast hücresi/nöron etkileşimlerinin düz kas hareketlerinde ve intestinal motilitede oluşturduğu fonksiyonel değişmeler rol oynayan birtakım mekanizmalardır. Süt alınmasından bir saat sonrasından günler sonrasına kadar olan sürede yakınmalar ortaya çıkabilir. Bundan dolayı genel olarak gecikmiş hipersensitivite olarak isimlendirilir. Hücresel aşırı duyarlılık ile gelişen besin reaksiyonlarının çoğunluğu özellikle bebek ve çocuklarda ortaya çıkan gastrointestinal sistemle ilgili aşırı duyarlılık reaksiyonlarıdır [10,11]. Bulantı, şişkinlik, intestinal rahatsızlıklar ve ishal gibi bulgular laktoz intoleransının birçok yakınmasına benzer ve bazen yanlış tanı konulmasına neden olabilir.

\section{KLİNIKK BULGULAR}

İSPA süt çocuklarında çok geniş bir yelpazede ve farklı şiddette yakınmalar oluşturabilir. Erken bulgular ve geç bulgular arasında ayrım yapmak yararlıdır. Erken bulgular alerjen alındıktan sonra birkaç dakika ile 2 saat arasında değişen sürede ortaya çıkar ve bunların IgE aracılı olma olasılığı daha yüksektir. Geç bulgular ise alerjen alındiktan 48 saat, hatta 1 hafta sonrasina kadar belirti verebilir [10] Alerjik olmayan reaksiyonların (toksik, farmakolojik) İSPA'yı taklit edebileceğini unutmamak gerekir. Genellikle birden fazla yakınma, birden fazla sisteme ait bulgu vardır. ISPA'nın izole olarak tek bir sistemi tutması çok nadirdir. Klinikte deri bulgularına \%50-60, gastrointestinal bulgularına \%50-60 ve solunum sistemi bulgularına $\% 20-30$ oranlarında rastlanır [1]. Yüzde 70 oranda birden çok sistemde aynı anda belirti verme eğilim gösterir.

Sindirim sistemindeki klinik belirti ve bulgular enflamasyona, dismotiliteye ve her ikisinin birlikte bulunmasına bağlı olabilir. Oral ve peroral şişlik, 
disfaji, kusma, regürjitasyon, dispepsi, erken doyma, anoreksi, gıda reddi (gecikmiş mide boşalmas1), ishal (malabsorpsiyonla veya enteropatiye bağl1 protein kaybı ile birlikte veya tek başına), gelişme geriliği, karın ağrısı, ciddi kolik ve inatçı kabızlık görülebilir $[1,12,13]$. Kronik demir eksikliği anemisi süt çocukları ve çocuklarda İSPA'nın tek bulgusu olabilir. Sadece anne sütü ile beslenen bebeklerde, inek sütü proteinlerine karşı duyarlanma, primer olarak atopik egzemanın alevlenmesine ve/veya alerjik proktokolitise neden olabilir. Ölüme yol açan nadir anaflaktik şok vakaları da bildirilmiştir [14]. ISSPA'nın klinik bulguları Tablo 1'de verilmiştir.

İSPA ayırıcı tanısında metabolik, anatomik bozukluklar, çölyak hastalığı ve diğer nadir enteropatiler, kistik fibrozis gibi pankreas yetmezlikleri, fruktoz intoleransı veya sekonder laktaz eksikliği gibi immünolojik olmayan besin intoleransı, yumurta, buğday gibi diğer besin alerjileri ve enfeksiyonlar dışlanmalıdır [1].

Tablo 1. Oluş mekanizmasına göre klinik bulgular

\begin{tabular}{lll}
\hline IgE aracılı & Non IgE aracılı & Kombine \\
\hline Deri & Deri & Deri \\
Ürtiker & Alerjik kontakt dermatit & Atopik egzema \\
Anjioödem & Dermatititis herpetiformis & \\
Morbiliform rash & & \\
Flushing & & \\
Gastrointestinal sistem (GiS) & Gis & GiS \\
Oral alerji sendromu & Enterokolit & Alerjik eozinofilik özofajit \\
Gastrointestinal anafilaksi & Alerjik eozinofilik gastroenterit & Alerjik eozinofilik gastroenterit \\
Enteropati & & \\
Çölyak & & \\
Solunum & & Solunum \\
Rinokonjunktivit & Solunum & Astım \\
Astım & Besin ile indüklenen pulmoner hemosiderozis & \\
Jeneralize & & \\
Anafilaksi & &
\end{tabular}

\section{TANI}

İSPA tanısında ilk ve en önemli basamak iyi alınmış bir öykü, atopik hastalıkları içeren detaylı özgeçmiş ve soygeçmiş sorgulaması ve fizik muayenedir. Birden fazla sistemi ilgilendiren yakınma ve bulguların varlığı ile atopi ve atopik hastalıklar açısından pozitif aile öyküsü İSPA düşündürür. İSPA şüphesi olan olgularda tanının alerjen eliminasyonu ve yükleme testi ile doğrulanması veya dışlanması gerekir [15]. Yakınmalara, öyküye ve çocuğun yaşına göre bu açık, tek veya çift kör yükleme testi şeklinde uygulanabilir. Ancak testlerin negatif olması tanı1 dışlamaz.

\section{Spesifik IgE ve cilt prick testi}

Her yaşta yararlı tanısal testlerdir. Spesifik IgE varlığ1 ve/veya inek sütüne karşı pozitif cilt prick testi
(CPT), inek sütü proteinine duyarlılığı gösterir. Tek başına tanı koydurmazlar, daima klinik ile birlikte değerlendirilmelidir. Antikor titresi ne kadar yüksekse ve CPT reaksiyonunun çapı ne kadar büyükse alerji gelişme olasıllğ 1 ve alerjinin devam etme riski o kadar yüksektir [16]. Gastrointestinal tutulumu olan çocuklarda, cilt bulguları olan çocuklarla karşılaştırıldığında spesifik IgE'nin negatif saptanma olasılığg daha fazladır.

\section{Atopi yama testi, total IgE ve intradermal testler}

Atopi yama testi IgE aracilı olmayan İSPA tanısında kullanılabilir. Ancak alerjenin hazırlanması, uygulanması ve sonucun değerlendirilmesi ile ilgili standartların olmaması nedeniyle günümüzde önerilmemektedir [17]. İSPA tanısinda total IgE'nin yeri yoktur. İntradermal testler, yüksek düzeyde duyarlı 
kişilerde sistemik alerjik reaksiyon riski taşıdığ için uygulanmamalıdır.

\section{Spesifik IgG antikorları ve diğer standardize edilmemiş testler}

İnek sütü proteinine karşı IgG antikorları veya $\operatorname{IgG}$ sinıf antikorlarının belirlenmesinin tanıda rolü yoktur [17]. Bazofil histamin salınım testi, lökosit migrasyon inhibisyonu, lenfosit transformasyon testi gibi diğer testler araştırma protokollerinde kullanılır, klinik uygulamada kullanılmamaktadır.

\section{Endoskopi ve histoloji}

Başka şekilde açıklanamayan anlamlı ve inatçı gastrointestinal sistem yakınmaları, gelişme geriliği veya demir eksikliği anemisi varlığında üst ve alt gastrointestinal sistem endoskopik biyopsileri alınması doğru bir yaklașımdır. Ancak mukozal atrofi, eozinofilik infiltrasyon gibi endoskopik ve histolojik bulgular İSPA'ya özgü değildir [18]. İSPA dışındaki hastalıkların tanısını koymaya olanak sağlar.

\section{İnek sütü proteininin diyetten çıkarılması}

Deri testleri ve spesifik IgE testi negatif olsa bile öykü destekliyorsa tanısal inek sütü proteini (süt ve

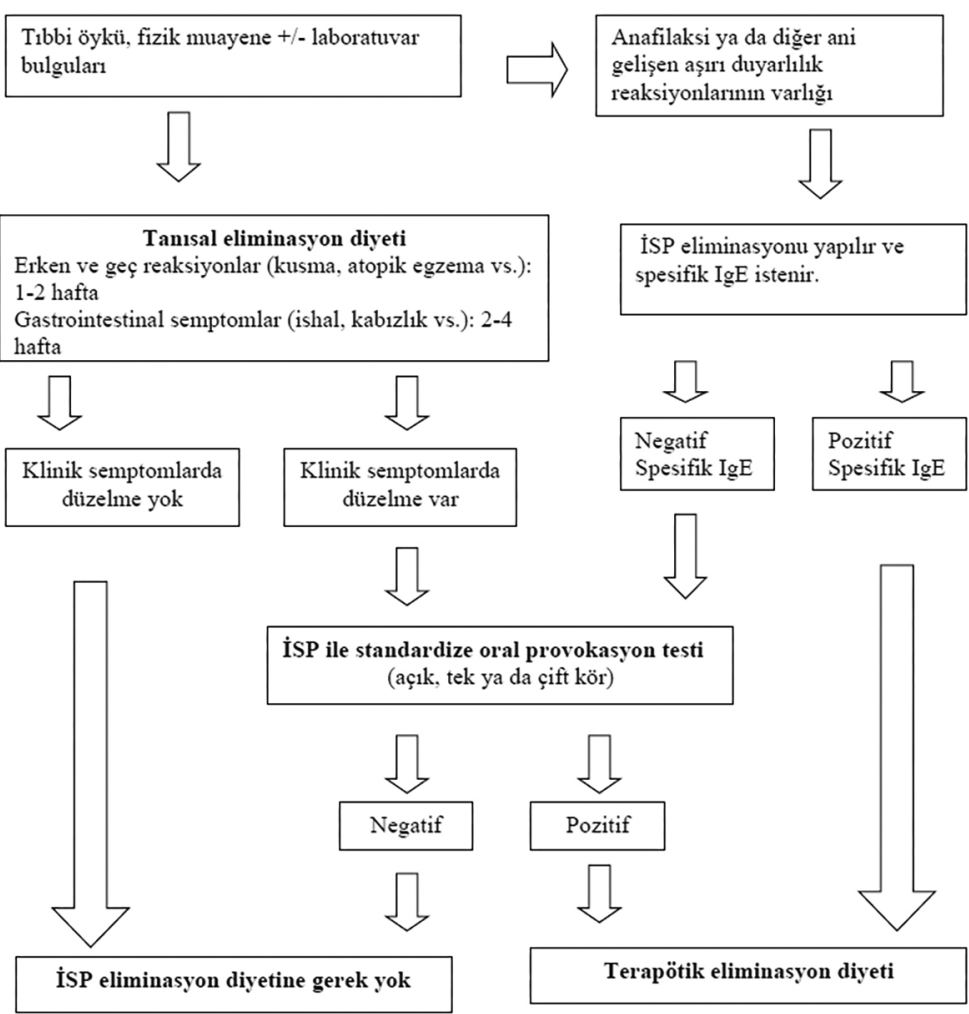

süt ürünleri) eliminasyonu yapılmalıdır (süt çocuğu/ çocuğun diyetinde veya anne sütü alıyorsa annenin diyetinde). Tanısal eliminasyon diyetinin süresi bulgulara bağlıdır, mümkün olduğu kadar kısa ve klinik yakınmaların düzelip düzelmediğini belirleyecek kadar uzun olmalıdır. Hızlı klinik reaksiyonları (2 saat içinde anjioödem, kusma, egzema alevlenmesi) olan çocuklarda bu süre 3-5 gün, gecikmiş klinik reaksiyonları (egzemanın alevlenmesi, rektal kanama) olanlarda 1-2 hafta arasında değişir. Kronik ishal, büyümede duraklama olan çocuklarda yanıtı değerlendirmek için inek sütü proteinsiz diyetin 2-4 hafta sürdürülmesi gerekir. Bu süreler içinde yakınmalarda düzelme olmazsa İSPA olasılığı düşüktür. Ancak istisnalar olabilir. Hidrolize mama veya soya içeren mama kullanan ve düzelme saptanmayan ciddi gastrointestinal bulguları olan süt çocukları, İSPA'yı dışlamadan önce aminoasit bazlı mama (AAF) ile bir süre gözlenmelidir [19]. Bu durum özellikle çoklu besin alerjisi olan hastalar için geçerlidir. Klinik yakınmalar AAF ile tanısal eliminasyon diyeti ile düzelmiyorsa, yakınmaların İSPA'ya bağlı olma olasılığ1 çok düşüktür. Bu nedenle mamanın uzun süreli kullanılması için endikasyon yoktur.
Şekil 1. İnek sütü protein alerjisi şüphesi olan çocukta uygulanması önerilen tanı ve tedavi algoritması ( ${ }^{*}$ ef 19). ISP: inek sütü proteini 
Anne sütü ile beslenen bebeklerde annenin diyetinden bütün süt ve süt ürünleri çıkarılarak emzirmeye devam etmesi için teşvik edilmelidir. Anneye gizli inek sütü proteini alımını engellemek için diyet danışmanlığ 1 verilmelidir. Ciddi yakınmaları olan ve anne sütü ile beslenen bebeklerde anne inek sütü proteini içermeyen diyete geçiş yaparken bebek terapötik bir mama ile beslenebilir [20].

\section{Besin yükleme testleri}

Besin alerjisi tanısında altın standart testlerdir. İlk bir yaşta açık kontrollü besin yükleme testi, 1-2 yaştan büyük çocuklarda ise çift kör plasebo kontrollü besin yükleme testi önerilir. Deri testleri ve spesifik IgE testi negatif olsa bile öykü kuvvetli ise yükleme testi yine de yapılmalıdır [1,19-21]. Ancak anafilaksi öyküsü varsa yükleme testi kontrendikedir. Yaşamın ilk yılında yükleme testi inek sütü bazlı bebek maması ile 12 aydan sonra taze pastörize inek sütü ile yapilmalıdır [19].

İSPA kesin tanısı inek sütü diyetten çıkarıldıktan sonra yakınmaların tamamen ortadan kalkmas1, inek sütü ile yükleme yapıldığında aynı yakınmaların ortaya çıkması, inek sütü diyetten tekrar çıkarıldığında yakınmaların kaybolması ile birlikte laktoz intoleransı ve eşzamanlı enfeksiyonların dışlanması ile konur (Şekil 1).

\section{TEDAVI VE IZLEM}

İSPA tedavinin temel prensipleri; doğru tanı, reaksiyonların tedavisi, eliminasyon diyeti, 2 yaş altındaki çocuklarda uygun mama kullanımı, destek tedavisi, büyüme ve gelişmenin takibi ve eğitime dayanır.

Anne sütü alan bebeklerde de İSPA olabileceği unutulmamalıdır. Bu bebeklerde anne sütüne devam edilmeli, klinik reaksiyonların annenin inek sütü alımı ile ilişskisi kesin olarak gösterilmişse, annenin diyetinden süt ve süt ürünleri çıkarılmalıdır. Annenin protein ve kalsiyum alımı izlenmelidir. Anneye günde $1000 \mathrm{mg}$ kalsiyum ve $10 \mathrm{mcg} \mathrm{D}$ vitamini desteği verilmelidir. Anne sütü almayan bebeklerde inek sütü proteini içermeyen mamaların kullanımı önerilmektedir. Bu amaçla AAF, yarı hidrolize mamalar, tam hidrolize mamalar (eHF), soya bazlı mamalar ve pirinç bazlı mamalar kullanılmaktadır [22]. Sadece AAF non-alerjiktir. Diğer mamalarda az da olsa rezidüel alerjenler olabilir. AAF'ler eHF'ye göre daha az reaksiyona neden olur ancak tadı daha kötüdür ve daha pahalıdır. Avrupa Pediatrik Gastroenteroloji, Hepatoloji ve Beslenme Derneği ve Amerikan Pediatri Akademisi İSPA'da ilk seçenek olarak eHF ve AAF'leri önermektedir [19,23].

Soya proteini içeren formulalar IgE aracılı İSPA'da alternatifler arasindayken, kolit ve enterokolit gibi IgE aracılı olmayan geç tip reaksiyonlarda önerilmez. Soyalı formulaların alüminyum içeriği yüksek olduğundan prematürelerde ve böbrek yetmezliği olan çocuklarda kullanılmamalıdır [1].

Diğer hayvan sütleri çapraz reaksiyon yapma riski nedeniyle rutin önerilmemektedir. İnek sütü proteini ile bufalo, koyun ve keçi sütü proteinleri arasında belirgin; at ve eşek sütü proteinleri arasında zayıf oranda çapraz reaksiyon saptanmıştır. Deve sütüne karş1 reaksiyon gösterilmemiştir. Bu bulgular fitogenetik farklılığa bağlanmıştır [1].

Tedavide esas olan inek sütü proteininden tam olarak kaçınmaktır. Günlük süt tüketimine bakıldığında tereyağı, peynir, yoğurt, tarhana çorbası, makarna, bisküvi, her türlü kek, kurabiye, dondurma, çikolatalı ürünler, kremalar gibi birçok gıda ürünü içerisinde inek sütü tüketilmektedir. Çocuğa, aileye ve çocuğa bakanlara diyet konusunda eğitim verilmesi ve hazır gida ürünlerinin etiketlerinde inek sütü içeren terimlerin öğretilmesi gerekmektedir (Tablo 2).

Tablo 2. Inek sütü bulunan besin etiketi içerikleri

Yapay tereyağ aroması

Tereyağ, süt, süt tozu, yoğurt, peynir

Kazeinat ( $\mathrm{Ca}$, amonyum, $\mathrm{K}, \mathrm{Na}$ )

Kazein

Hidrolizat (kazein, süt proteini, protein, whey)

Keçi sütü

Laktalbümin

Laktoglobulin

Laktüloz

Whey

Çikolata

Margarin

\section{PROGNOZ}

İSPA yaşla birlikte düzelmektedir. Hastaların \%50'sinde 1 yaşında, \%75'inde 3 yaşında, 
\%90'ında 6 yaşında tolerans gelişir [7]. İSPA'nın devam ettiği hastalarda atopi ve pozitif aile öyküsü daha sıktır. Özellikle spesifik IgE değerleri yüksek olanlarda yakınmaların geç yaşlara kadar devam ettiği görülür. Eliminasyon süresi çocuğun yakınmalarının ciddiyetine, spesifik IgE pozitifliğine bağlı olarak değişir. En az 6 ay veya 6-9. aya kadar eliminasyona devam edilmelidir. Ciddi ani IgE ilișkili reaksiyonlarda eliminasyon süresi 12-18. aya kadar uzatılabilir [17].

\section{SONUÇ}

İSPA tanıs1 süt çocukluğunda doğru ve özenle konulmalıdır. Yanlış tanı; gereksiz diyet ve gerçek nedeni atlamaya neden olur.

\section{KAYNAKLAR}

1. Tamay Z. İnek Sütü Alerjisi. Klinik Tıp Pediatri 2010;2:1418.

2. Wal JM. Cow's milk allergens. Allergy 1998;53:1013-1022.

3. Fiocchi A, Schünemann HJ, Brozek J, et al. Diagnosis and rationale for action against cow's milk allergy (DRACMA): a summary report. 2010;126:1119-1128.

4. Chatchatee P, Jarvinen KM, Bardina L, et al. Identification of IgE and Ig G binding epitopes on alpha (s1)-casein: differences in patients with persistent and transient cow's milk allergy. J Allergy Clin Immunol 2001;379-383.

5. Altıntaş DU. İnek Sütü Allerjisi. Turkiye Klinikleri J AllergyAsthma 2003;5:164-167.

6. Sichere SH. Epidemiology of food allergy. J Allergy Clin Immunol 2011;127:594-602.

7. Host A, Halken S, Jacopsen HP, et al. Clinical course of cow's milk protein allergy/intolarence and atopic diseases in childhood. Pediatr Allergy Immunol 2002;13:23-28.

8. Arıcan Ö, Hacımustafaoğlu OY. Besin Alerjisi. Kartal Eğitim ve Araştırma Hastanesi Tıp Dergisi 2002;13:142-145.

9. Sapan N, Demir E, Tamay Z, ve ark. 'Çocuk alerji ve astım akademisi', besin alerjisi tanı ve tedavi protokolü. Türk Ped Arş 2013;270-274.

10. Shek LP, Bardina L, Castro R, et al. Humoral and cellular responses to cow milk proteins in patients with mil-induced
IgE and non-IgE- mediated disorders. Allergy 2005;60:912919.

11. Sampson HA. Food Allergy. J Allergy Clin Immunol 2003;111:540-547.

12. Spergel JM. Eosinophilic esophagitis in adults and children: evidence for a food: allergy component in many patients. Curr Opin Allergy Clin Immunol 2007;7:274-278.

13. Arvola T, Ruuska T, Keranen J, et al. Rectal bleeding in infancy: clinical, allergological, and microbiological examinition. Pediatrics 2006;117:760-768

14. Sampson HA, Mendelson L, Rosen JP. Fatal and near-fatal anaphylactic reactions to food in children and adolescents. N Engl J Med 1992;327:380-384.

15. Dupont C. Diagnosis of cow's milk allergy in children: determining the gold standard? Expert Rev Clin Immunol 2014; 10:257-267.

16. Skripak JM, Matsui EC, Mudd K, et al. The natural history of IgE mediated cow's milk allergy. J Allergy Clin Immunol 2007;120:1172-1177.

17. Boyce JA, Assa'ad A. Burks AW, et al. Guidelines for diagnosis and management of food allergy in the United States: report of the NIAID sponsored expert panel. J Allergy Clin Immunol 2010;126:1-58.

18. Nielsen RG, Fenger C, Bindslev-Jensen C, et al. Eosinophilia in the upper gastrointestinal tract is not a characteristic feature in cow's milk sensitive gastro-oesophageal reflux disease. Measurement by two methodologies. J Clin Pathol 2006;59:89-94.

19. Koletzko S, Niggemann B, Arato A, et al. Diagnostic Approach and Management of Cow's milk protein allergy in infants and children: ESPGHAN GI Committee Practical Guidelines. J Pediatr Gastroenterol Nutr 2012;55:221-229.

20. Kneepkens CM, Meijer Y. Clinical practice. Diagnosis and treatment of cow's milk allergy. Eur J Pediatr 2009;168:891-896.

21. Vandenplas Y, De Greef E, Devreker T. Treatment of cow's milk protein allergy. Pediatr Gastroenterol Hepatol Nutr 2014;17:1-5

22. Reche M, Pascual C, Fiandor A, et al. The effect of a partially hydrolysed formula based on rice protein in the treatment of infants with cow's milk protein allergy. Pediatr Allergy Immunol 2010;4:577-585.

23. American academy of Pediatrics. Committee on nutrition. Hypoallergenic formulas. Pediatrics 200;106:349-349. 